R, Tripathi M. Clinical predictors and outcome of patients of acute stroke requiring ventilatory support: A prospective hospital based cohort study. Journal of the Neurological Sciences. 2014;337(1-2):14-17.

2. Vũ Anh Nhị, Trân Thanh Hùng (2012), "Kiểm định các yếu tố tiên lượng đột quy cấp có đă̆t nội khí quản", Tap chí Y dược lâm sàng 108, 7 (số đặc biệt), tr. 267-270.

3. Berrouschot J, Rössler A, Köster J, Schneider D. Mechanical ventilation in patients with hemispheric ischemic stroke: Critical Care Medicine. 2000;28(8):2956-2961.

4. Nguyễn Hồng Quân, Nguyễn Văn Thông (2012), "Nghiển cứu đắc điểm lâm sàng và môtt số yếu tố tiên lượng bênh nhân đột quy có đặt nội khí quản", Tap chí Y dược lâm sàng 108 , số 7(Số đặc biệt), tr. 234 - 240.
5. Santoli F, De Jonghe B, Hayon J, et al. Mechanical ventilation in patients with acute ischemic stroke: survival and outcome at one year. Intensive Care Med. 2001;27(7):1141-1146.

6. Walcott BP, Miller JC, Kwon C-S, et al. Outcomes in Severe Middle Cerebral Artery Ischemic Stroke. Neurocrit Care. 2014;21(1):20-26.

7. Schielke E, Busch MA, Hildenhagen $T$, et al Functional, cognitive and emotional long-term outcome of patients with ischemic stroke requiring mechanical ventilation. J Neurol. 2005;252(6):648-654.

8. Trân Thị Oanh (2018). Nghiên cứu đăc điểm lâm sàng, cận lâm sàng và một số yếu tố liền quan của bệnh nhân nhồi máu não cấp trên lều tiểu não có thông khí cơ hoc. :27.

9. Mayer SA, Copeland D, Bernardini GL, et al. Cost and Outcome of Mechanical Ventilation for LifeThreatening Stroke. Stroke. 2000;31(10): 2346-2353.

\title{
ĐÁNH GIÁ KẾT QUẢ ĐIỀU TRI DUY TRÌ DOCETAXEL TRÊN BÊ̂NH NHÂN UNG THƯ PHỔI KHÔNG TẾ BÀO NHỎ GIAI ĐOẠN MUộN TẠI BỆNH VIỆN UNG BƯỚU NGHỆ AN
}

\section{Nguyễn Quang Trung*, Phạm Vĩnh Hùng*, Nguyễn Viết Bình*, Nguyễn Khánh Toàn*, Phạm Thị Hường \\ DOCETAXEL IN ADVANCED STAGE NON SMALL CELL LUNG CANCER AT NGHE AN ONCOLOGY HOSPITAL}

\section{TÓM TẮT}

Mục tiêu: Đánh giá hiệu quả, độc tính của phác đồ Docetaxel duy trì trên bệnh nhần ung thư phối không tế bào nhỏ giai đoạn muộn tại BVUBNA. Đối tượng và phương pháp nghiên cứu: Nghiên cứu hồi tiển cứu trên 47 bênh nhân ung thư phổi không tế bào nhỏ giai đoan muộđươợc điều trị duy trì Docetaxel sau khi điêu trị bước 1 bằng phác đồ hóa trị bộ đôi đạt đáp ứng hoăc bênh ổn đinh tai Bênh viên Ung bướu Nghệ An từ tháng 1/2016 đển tháng 8/2020. Kết quả: Tuổi TB của nhóm nghiên cứu là 62,5 $\pm 7,06$; Tỷ lế nam/ nữ $3,7 / 1$. Có $1 B N$ đáp ứng hoàn toàn $(2,3 \%)$; $34 \%$ đáp ứng 1 phần; $38,3 \%$ bênh ổn đinh. Thời gian sống thêm không tiến triển $9.0 \pm 0.4$ tháng, thời gian sống thêm toàn bộ 18,7 tháng. Các tác dụng không mong muốn: Giảm huyết sắc tổ $78.7 \%$, giảm bạch câu là $46.7 \%$, giảm bach câu có sốt là $17,1 \%$ trong đó $4.3 \%$ ở độ 3. Tăng men gan (21,3\%), Nôn và buồn nôn $(27.6 \%)$. Hầu hết ở độ 1- 2 . Kết luận: Điều trị Docetaxel duy trì cho hiệu quả cao và dung nạp thuốc tốt ở bênh nhân UTPKTBN giai đoan muôn

Từ khóa: Ung thư phổi khônng tế bào nhỏ giai đoạn muộn, Docetaxel duy trì

\section{SUMMARY}

\section{THE EFFICALLY OF MAINTANCE}

*Bệnh Viện Ung Bướu Nghê An

Chịu trách nhiệm chính: Phạm Thị Hường

Email: Bshuongn2ub@gmail.com

Ngày nhận bài: 8.9.2021

Ngày phản biên khoa hoc: 27.10.2021

Ngày duyệt bài: 11.11.2021
Objective: Effect and side effect of maintance Docetaxel in advance stage non-small cell lung cancer. Patients and method of study: Retrospective and prospective study on 47 non-small cell lung cancer patients in advanced stage after first- line treatmentdouble- platinum chemotherapy from January 2016 to August 2020. Results: Median of age $62,5 \pm 7,06$; Male/Female:3,7/1. A patient completely responded $(2,3 \%), 34 \%$ partial respone, stable disease rate $38,3 \%$. Mean Progression free survival $9.0 \pm 0.4$ months, overal survival 18,7 months. Side effects: anemia $78,7 \%$, neutropenia $46,7 \%$, transaminase elevation $21,3 \%$, nausea and vomiting $(27,6 \%)$. Almost side effects are grade $1-2$.

Key word: Advance stage Non small cell lung cancer, Maintance docetaxel.

\section{I. ĐĂT VẤN ĐỀ}

Ung thư phổi (UTP) là bệnh lý ác tính và là nguyên nhân gây tử vong do ung thư thường gặp nhất trên toàn cầu. Theo thống kê của Tồ chức nghiên cứu ung thư quốc tế IARC (Globocan 2018), ước tính có khoảng 2,1 triệu ca UTP mới mắc, chiếm $11,6 \%$ tổng số bệnh nhân ung thư và 1,8 triêu người tử vong, chiếm 18,4 $\%$ tổng số ca tử vong do ung thư nói chung [1]. Tại Việt Nam, các kết quả ghi nhận ung thư quần thể cũng cho thấy UTP có tỷ lệ mắc và tử vong cao ở cả hai giới[2]. Theo phân loại của Tổ chức 
Y tế thế giới WHO, UTP được chia làm 2 nhóm chính dựa trên đặc điểm mô bênh học là ung thư phổi không tế bào nhỏ (UTPKTBN) chiếm 80$85 \%$ và ung thư phổi tế bào nhỏ (10-15\%).

Hầu hết bệnh nhân đến viện ở giai đoạn muộn, không còn khả năng phẫu thuật. Từ những năm 1990 hầu hết các nghiên cứu trên thế giới đều cho thấy hóa trị dựa trên phác đồ chứa Platinum kết hợp với các thuốc được xem như thế hệ thứ ba (Gemcitabine, các Taxane, Vinorelbine...) không những làm tăng tỷ lệ đáp ứng, kéo dài thời gian sống thêm mà còn cải thiện được chất lượng cuộc sống và kiểm soát được các triệu chứng của bệnh. Vai trò của Docetaxel trong điều trị duy trì UTPKTBN giai đoạn muộn đã được chứng minh trong nhiều nghiên cứu. Các nghiên cứu này cho thấy cải thiện triệu chứng, kéo dài thời gian sống thêm với độc tính chấp nhận được[3].

Tại Bệnh viện Ung bướu Nghệ An từ nhiều năm nay đã áp dụng điêu trị Docetaxel duy trì cho bệnh nhân UTPKTBN giai đoạn muộn sau khi điều trị bước 1 hóa trị bộ đôi Platinum và cho kết quả khả quan nhưng chưa có nghiên cứu nào đánh giá hiệu quả của thuốc. Vì vậy, chúng tôi tiến hành đề tài nghiên cứu này với mục tiêu sau: Đánh giá hiệu qủa, độc tính của phác đồ Docetaxeltrên bệnh nhân ung thư phổi không tế bào nhỏ giai đoạn muộn tại BVUBNA.

\section{II. ĐỐI TƯỢNG VÀ PHƯƠNG PHÁP NGHIÊN CỨU}

2.1. Đối tượng nghiên cứu: Gồm 47BN UTPKTBN giai đoạn muộn được điều trị duy trì Docetaxel sau khi điêuu trị bước 1 bằng phác đồ hóa trị bộ đôi đạt đáp ứng hoặc bệnh ổn định tại Bệnh viện Ung bướu Nghệ An từ tháng 1/2016 đển tháng 8/2020.

\section{*Tiêu chuân lứa chon}

- Bệnh nhân được chẩn đoán UTPKTBN

- Giai đoạn IIIB, IIIC, IV

- Điều trị đủ 4 - 6 ck hóa trị bộ đôi platinum đạt đáp ứng hoặc bệnh ổn định

- Điều trị duy trì Docetaxel tối thiểu 3 đợt

- Không có đột biến hoặc không rõ tình trạng gen EGFR, ALK

- Chỉ số toàn trạng PS 0 - 2

- Chức năng gan, thận, huyết học cho phép hóa chất

- Có đầy đủ thông tin

- Chấp nhận tham gia nghiên cứu

*Tiêu chuẩn loại trừ

Chống chỉ định truyền hóa chất

- Những BN ngưng dùng thuốc (khi bệnh chưa có dấu hiệu tiến triển) vì lý do chủ quan của $\mathrm{BN}$ và người nhà, $\mathrm{BN}$ từ chối hợp tác, không theo dõi được.

- Được biết hoă̆c nghi ngờ quá mẫn với bất kỳ thành phần nào của thuốc

- Phụ nữ có thai hoăcc cho con bú.

\subsection{Phương pháp nghiên cứu}

2.3.1. Thiết kế nghiên cứu: nghiên cứu mô tả, hồi tiến cứu.

2.3.2. Thu thập thông tin: Mỗi $B N$ được thu thập thông tin theo mẫu bệnh án nghiên cứu thống nhất, dựa trên các thông tin hồi cứu từ bênh án được lưu trữ.

\subsection{3. Điều trị}

- Phác đồ điều trị: Docetaxel $75 \mathrm{mg} / \mathrm{m} 2$ truyền TM ngày 1 , chu kỳ 21 ngày.

Điều trị đến khi bệnh tiến triển hoặc độc tính không chấp nhận được.

- Trong quá trình điều trị BN được ghi nhận lâm sàng, cận lâm sàng, đáp ứng điều trị, PFS, OS, độc tính của phác đồ

2.4. Phương pháp xử trí phân tích số liệu: phần mềm SPSS 20.0

III. KẾT QUẢ VÀ BÀN LUẬN

3.1. Đặc điểm đối tượng nghiên cứu 3.1.1. Tuổi và giới

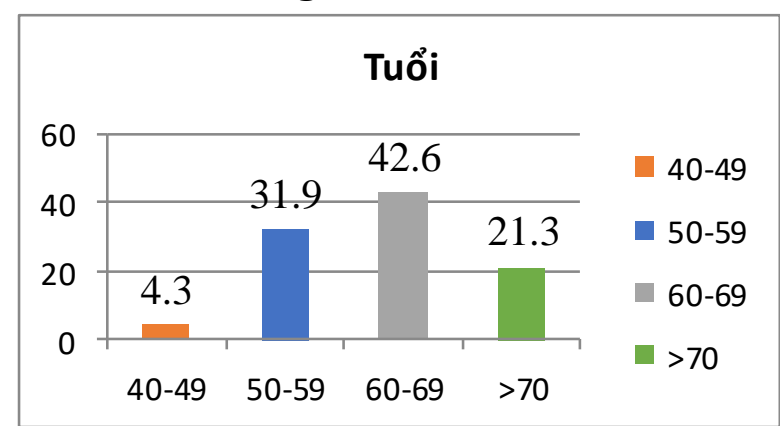

Biểu đồ 3.1. Phân bố người bệnh theo nhóm tuổi

Tuổi và giới là những yếu tố quan trọng trong các nghiên cứu về bệnh ung thư. Tuổi phản ánh quá trình tích lũy, thời gian tiếp xúc với các tác nhân gây bênnh. Theo hầu hết các thống kê về ung thư phổi, tuổi thường gặp 35-75, đỉnh cao từ $55-75$ tuổi. Trong nghiên cứu của chúng tôi tỷ lệ UTP cao nhất ở nhóm tuổi $60-69$. Tuổi mắc bệnh trung bình là $62,5 \pm 7,06$; cao nhất là 75 tuổi, thấp nhất là 47 tuổi. Các nghiên cứu trên thế giới đều ghi nhận rằng, nam giới có tỷ lệ mắc UTP cao hơn nữ giới. Tỷ lệ nam/nữ dao động từ 2,5-4/1. Nghiên cứu của chúng tôi cho thây số bệnh nhân nam/ nữ = 3.7/1[4].

3.1.2. Chỉ số toàn trạng (PS) 


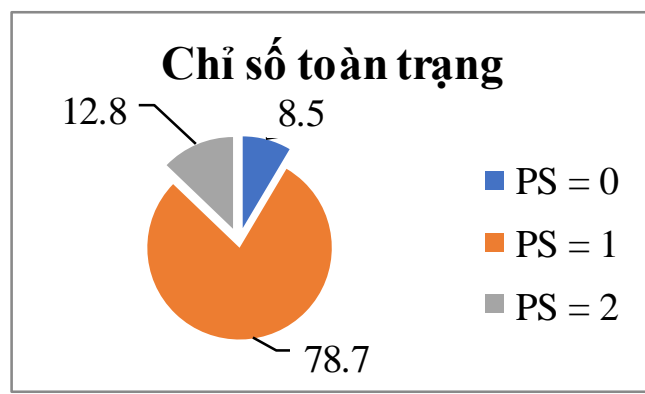

Biểu đồ 3.2.Chỉ sô toàn trạng

PS là chỉ số đánh giá toàn trạng bệnh nhân trước điều trị, cũng như để theo dõ̉i tình trạng sức khỏe người bệnh tốt lên hay xấu đi trong quá trình trị bệnh.Trong nghiên cứu của chúng tôi đa phần bệnh nhân có $\mathrm{PS}=1$ (chiếm $78.7 \%$ ) và $12.8 \%$ bểnh nhân có chỉ số toàn trạng $P S=2$. Điều này phù hợp với báo cáo của các nghiên cứu trong những năm gần đây, đối với bệnh nhân ung thư phổi giai đoạn muộn được điều trị hoá trị đa phần bệnh nhân có chỉ số toàn trạng PS $\leq 2$ [5]

\subsubsection{Mô bệnh học}

Bảng 3.1. Mồ bệnh học

\begin{tabular}{|c|c|c|}
\hline Mố bệnh học & Số BN (n) & Tỷ lệ (\%) \\
\hline UTBM tuyên & 29 & 61.7 \\
\hline UTBM vảy & 16 & 34 \\
\hline UTPKTBN & 2 & 4.3 \\
\hline Tống & $\mathbf{4 7}$ & $\mathbf{1 0 0}$ \\
\hline
\end{tabular}

Trong nghiên cứu của chúng tôi tỷ lệ UTBM tuyến cao nhất chiếm $61.7 \%$, UTBM vảy chiếm $34 \%$, UTPKTBN chiếm $4.3 \%$. Các nghiên cứu gần đây cũng đề cập đến việc gia tăng tỷ lệ UTBM tuyến. Tổng kết về ung thư phổi và bệnh nhân phẫu thuật phổi tại trung tâm ung thư MD Andeson từ năm 1987 - 1991 cho kết quả UTBM tuyến là $47 \%$, UTBM vảy là $34-36 \%$. Theo tác giả Fidias (2009) tỷ lệ UTBM tuyến là $54.9 \%$ và UTBM vảy là $16.3 \%$ [6].

\subsection{4. Đáp ứng sau điêu trị Bước 1}

Bảng 3.2. Đáp ứng sau điều trị bước 1

\begin{tabular}{|c|c|c|}
\hline Triệu chứng & Số $\mathbf{B N}$ (n) & Tỷ lệ (\%) \\
\hline Đáp ứng hoàn toàn & 0 & 0 \\
\hline Đáp ứng một phần & 21 & 44.7 \\
\hline Bệnh ổn định & 26 & 55.3 \\
\hline Tống & $\mathbf{4 7}$ & $\mathbf{1 0 0}$ \\
\hline
\end{tabular}

Trong nghiên cứu này, sau điêu trị bước 1 không có bệnh nhân nào đáp ứng hoàn toàn, có $44.7 \% \mathrm{BN}$ đáp ứng một phần và $55.3 \%$ bệnh ổn định. Theo báo cáo của tác giả Fidias (2009 tỉ lệ đáp ứng một phần $(29.8 \%)$, bệnh ổn định $(43,3 \%)[6]$.
3.2. Đáp ứng điêu trị
3.2.1.Tỷ lệ đáp ứng
Bảng 3.3. Đáp ứng khách quan

\begin{tabular}{|c|c|c|}
\hline Đáp ứng & Số BN $\mathbf{~ ( n ) ~}$ & Tỷ lệ (\%) \\
\hline Đáp ứng hoàn toàn & 1 & 2.3 \\
\hline Đáp ứng một phần & 16 & 34 \\
\hline Bệnh giữ nguyên & 18 & 38.3 \\
\hline Bệnh tiến triến & 12 & 25.5 \\
\hline Tống & $\mathbf{4 7}$ & $\mathbf{1 0 0}$ \\
\hline
\end{tabular}

Trong nghiên cứu của chúng tôi có $1 \mathrm{BN}$ đáp ứng hoàn toàn (chiếm 2.3\%); $16 \mathrm{BN}$ đáp ứng một phần chiếm tỷ lệ $34 \%$ và 18 bệnh nhân bệnh ổn định chiếm tỳ lệ $38.3 \%$. Theo tác giả Fidias (2009) khi so sánh nhóm bệnh nhân điêuu trị Docetaxel duy trì so với việc trì hoãn Docetaxel cho đến khi bệnh tiến triển, kết quả cho thấy đối với nhóm Docetaxel ngay lập tức $(n=145)$, bảy bệnh nhân $(4,8 \%)$ đáp ứng hoàn toàn, 45 bệnh nhân $(31,0 \%)$ đáp ứng một phần, 53 bệnh nhân (36,6\%) bệnh ổn định, 19 bệnh nhân $(13,1 \%)$ tiến triển và 21 bệnh nhân (14,5\%) không rõ. Tỷ lệ đáp ứng toàn bộ là 35,9\% [6].

\subsubsection{Thời gian sông thêm}

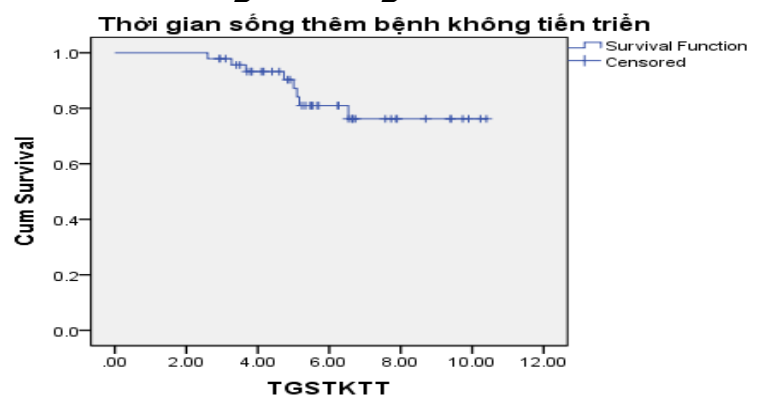

\section{Biểu đồ 3.3. Sống thêm không tiên triển}

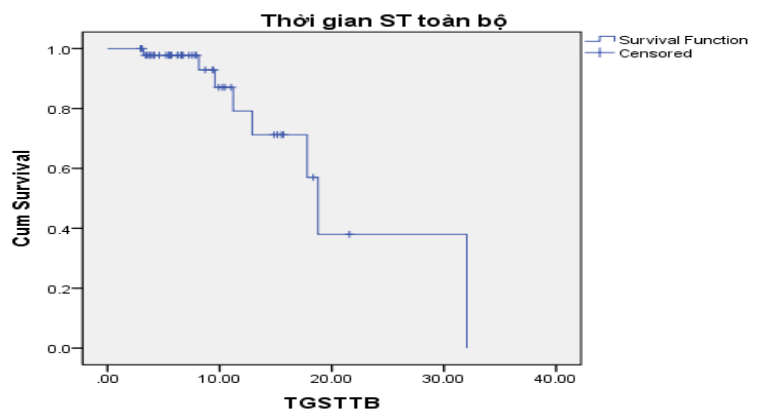

Biểu đồ 3.4. Thời gian sống thêm toàn bộ

Đối với những bệnh nhân UTPKTBN giai đoạn muộn thì không có chỉ định điều trị triệt căn và mục đích chính của các phương pháp điều trị bệnh ở giai đoạn này là nhằm cải thiện các triệu chứng của bệnh và kéo dài thời gian sống thêm. Trong nghiên cứu chúng tôi, thời gian sống thêm bệnh không tiến triển trung bình là $9.0 \pm 0.4$ tháng cao hơn tác giả Fidias (2009) với trung vị PFS là 5,7 tháng ở nhóm điều trị Docetaxel duy trì so với nhóm trì hoãn là 2.7 tháng $(P=.0001)$ hay tác giả Li Zhang (2013) 
khi so sánh điều trị Docetaxel duy trì so với chăm sóc triệu chứng, trung vị thời gian sống thêm bệnh không tiến triển lần lượt là 5,4 tháng so với 2,8 tháng $(P=0,002)$. Theo báo cáo của Lã Duy Tuyến (2019) thời gian sống thêm bệnh không tiến triển trung bình là 8.7 tháng, trung vị thời gian sống thêm toàn bộ 18,7 tháng. Tỷ lệ sống 1 năm là $76.5 \%$. Kết quả này cao hơn so với kết quả của Lã Duy Tuyến (2019) là 16,6 tháng hay tác giả Fidias (2009) là 12,3 tháng. Điều này có thể do trong nghiên cứu của chúng tôi có một tỷ lệ bệnh nhân giai đoạn IIIB, IIIC hay kết quả của việc áp dụng những tiến bộ về chăm sóc giảm nhẹ, điều trị bổ trợ hay việc quản lí tốt tác dụng phụ của thuốc. [6],[7],[8].

\subsubsection{Tác dụng phụ trên hệ huyết học}

Bảng 3.4. Tác dụng phụ trên huyết học

\begin{tabular}{|c|c|c|c|c|c|c|c|c|c|c|}
\hline \multirow{2}{*}{ Tác dụng phụ } & \multicolumn{2}{c|}{ Không } & \multicolumn{2}{c|}{ Độ I } & \multicolumn{2}{c|}{ Độ II } & \multicolumn{2}{c|}{ Độ III } & \multicolumn{2}{c|}{ Độ IV } \\
\cline { 2 - 11 } & $\mathbf{n}$ & $\mathbf{\%}$ & $\mathbf{n}$ & $\mathbf{\%}$ & $\mathbf{n}$ & $\mathbf{\%}$ & $\mathbf{n}$ & $\mathbf{\%}$ & $\mathbf{n}$ & $\%$ \\
\hline Giảm bạch cầu & 26 & 53.3 & 18 & 38.3 & 3 & 6.4 & 0 & 0 & 0 & 0 \\
\hline Sốt hạ BC & 39 & 82.9 & 3 & 6.4 & 3 & 6.4 & 2 & 4.3 & 0 & 0 \\
\hline Giảm huyết sắc tố & 10 & 21.3 & 29 & 61.7 & 8 & 17 & 0 & 0 & 0 & 0 \\
\hline Giảm tiếu cầu & 40 & 85.1 & 7 & 14.9 & 0 & 0 & 0 & 0 & 0 & 0 \\
\hline
\end{tabular}

Tác dụng không mong muốn hay gặp nhất là giảm huyết sắc tố $(78.7 \%)$, chủ yếu ở mức độ nhẹ (độ 1 , độ 2 ). Giảm bạch cầu chủ yếu gặp ở mức độ nhẹ $(46.7 \%)$, có 2 bệnh nhân sốt hạ bạch cầu (4.3\%), không có bệnh nhân nào phải giảm liều hóa chất hay bỏ dở điều trị. Giảm tiều cầu ít gặp, chỉ 14.9\% bệnh nhân gặp ở độ 1, thường tự hồi phục sau khi ngừng hóa chất.

\subsubsection{Tác dụng phụ ngoài hệ huyết học}

Bảng 3.5. Tác dụng phụ ngoài hê huyêt học

\begin{tabular}{|c|c|c|c|c|c|c|c|c|c|c|}
\hline Tác dưng phụ & \multicolumn{2}{|c|}{ Không } & \multicolumn{2}{c|}{ Độ I } & \multicolumn{2}{c|}{ Độ II } & \multicolumn{2}{c|}{ Độ III } & \multicolumn{2}{c|}{ Độ IV } \\
\cline { 2 - 11 } & $\mathbf{n}$ & $\mathbf{\%}$ & $\mathbf{n}$ & $\mathbf{\%}$ & $\mathbf{n}$ & $\mathbf{\%}$ & $\mathbf{n}$ & $\mathbf{\%}$ & $\mathbf{n}$ & $\mathbf{\%}$ \\
\hline Buồn nôn- nôn & 34 & 72.3 & 9 & 19.1 & 4 & 8.5 & 0 & 0 & 0 & 0 \\
\hline Tiêu chảy & 39 & 83 & 7 & 14.9 & 1 & 2.1 & 0 & 0 & 0 & 0 \\
\hline Thần kinh ngoại vi & 28 & 59.6 & 15 & 31.9 & 4 & 8.5 & 0 & 0 & 0 & 0 \\
\hline Dau cơ khớp & 32 & 68.1 & 15 & 31.9 & 0 & 0 & 0 & 0 & 0 & 0 \\
\hline Tăng men gan & 34 & 72.3 & 10 & 21.3 & 0 & 0 & 0 & 0 & 0 & 0 \\
\hline Tăng Creatinin & 2 & 4.3 & 0 & 0 & 0 & 0 & 0 & 0 & 0 & 0 \\
\hline
\end{tabular}

Tỷ lê buồn nôn và nôn là một biến chứng thường gắp với đô 1 chiếm $19.1 \%$ và đô 2 là $8,5 \%$; biến chứng này có thể kiếm sát được bằng thuốc. Tỷ lệ đau cơ khớp và thần kinh ngoại vi chủ yếu ở mức độ nhe (độ 1 ) lần lượt là $31.9 \%$ và $40.4 \%$. Tình trạng tăng men gan mức độ nhẹ, chiếm tỷ lệ nhỏ và tự hồi phục. Có 2 bệnh nhân tăng creatinin độ 1 (4.3\%).

\section{KẾT LUÂ̂N}

- Tuổi mắc bệnh TB là $62,5 \pm 7,06$. Tuổi có nguy cơ cao trong NC là $60-69$ tuổi.

- Tỷ lệ nam/nữ là 3.7/1.

- Có 1 Bn đáp ứng hoàn toàn $(2,3 \%), 34 \%$ đáp ứng 1 phần; 38,3\% bệnh ổn định.

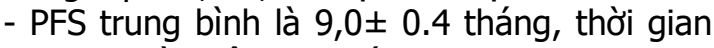
sống them toàn bộ 18,7 tháng

- TDKMM hay gặp nhất là giảm huyết sắc tố (78.7\%), giảm bạch cầu nhẹ (46.7\%), tăng men gan $(21,3 \%)$, buồn nôn và nôn $(27,6 \%)$.

\section{TÀI LIÊU THAM KHẢO}

1. International Agency for Research on Cancer (2012). Estimated Cancer Incidence, Mortality and Prevalence Worldwide 2012.

2. Bùi Diệu, Nguyển Bá Đức, Trân Văn Thuấn (2010). Tình hình mắc ung thư tại Việt Nam 2004-2008 qua số liệu của 6 vùng. Tạp chí ung thư học Việt Nam, 1/2010, 75-77.
3. Coate LE, Shepherd FA. Maintenance therapy in advanced non-small cell lung cancer: evolution, tolerability and outcomes. Ther Adv Med Oncol. 2011;3(3):139-157. doi: $10.1177 / 1758834011399306$

4. Nguyển Bá Đức, Bùi Công Cường, Trân Văn Thuấn (2007). Ung thư phổi. Chẩn đoán và điều trị bệnh ung thư, 176-187.

5. Paz-Ares $L$, de Marinis $F$, Dediu $M$, et al. Maintenance therapy with pemetrexed plus best supportive care versus placebo plus best supportive care after induction therapy with pemetrexed plus cisplatin for advanced non-squamous non-small-cell lung cancer (PARAMOUNT): a double-blind, phase 3, randomised controlled trial. Lancet Oncol 2012; 13:247.

6. Fidias PM, Dakhil SR, Lyss AP, et al. Phase III study of immediate compared with delayed docetaxel after front-line therapy with gemcitabine plus carboplatin in advanced non-small-cell lung cancer. J Clin Oncol 2009; 27:591.

7. Lã Duy Tuyến (2019). Đánh giá hiệu quả điều tri duy trì Pemetrexed trong ung thư phổi không tế bào nhỏ, không vảy giai đoạn muộn sau điều trị 
hóa chất bước 1 Pemetrexed - cisplatin. Tạp chí ung thư học Việt Nam.

8. Li, P., et al. (2013). "Different-dose docetaxel plus cisplatin as first-line chemotherapy and then maintenance therapy with single-agent docetaxel for advanced non-small cell lung cancer (TFINE study, C-TONG 0904)." Journal of Clinical Oncology 31: 8015-8015.

\section{ĐĂC ĐIỂM LÂM SÀNG, CÂ̂N LÂM SÀNG Ở BỆNH NHÂN LUPUS BAN ĐỎ HỆ THỐNGCÓ KHÁNG THỂ ANTI-SMITH DƯƠNG TÍNH}

\section{TÓM TẮT}

Mục tiêu: Nghiên cứu nhằm mô tả đặc điểm lâm sàng, cận lâm sàng ở bệnh nhân lupus ban đỏ hệ thống có kháng thể anti-Śmith dương tính. Phương pháp nghiên cứu: Đây là nghiên cứu mô tả cắt ngang trên 118 bệnh nhân được chẩn đoán lupus ban đỏ hệ thống theo tiêu chuẩn SLICC 2012 điều trị tại Trung Tâm Dị Ứng Miễn Dịch Lâm Sàng Bệnh viện Bạch Mai từ tháng 7/2020 đến tháng 9/2021. Kết quả: $51.7 \%$ bệnh nhân có kháng thể anti-Sm dương tính; tập trung chủ yếu trong độ tuổi sinh đẻ; tỷ lệ nữ/nam là 9.7:1; tuổi trung bình là $31.53 \pm 11.786$ tuổi. Kháng thể anti-Sm dương tính liên quan đến giảm bổ thể C4 $(p<0.001)$; không liên quan đếnban da cấp tính $(p=0.057)$, loét niêm mạc $(p=0.103)$, viêm khớp $(p=0.374)$, tràn dịch màng tim $(p=0.243)$, tràn dich màng phổi $(p=0.426)$, viêm khớp $(p=0.374)$, tổn thương thận ở mức viêm cầu thận hoặc hội chứng thân hư $(\dot{p}=0.579)$, giảm bạch cầu $(p=0.582)$, giảm tiểu câu $(p=0.347)$, giảm bổ thể $C 3(p=0.078)$ và kháng thể kháng chuổi kép dsDNA dương tính $(p=0.187)$.Điểm SLEDAI trung bình ở hai nhóm dương tính và âm tính (lần lượt là $13.39 \pm 5.499$ và $12.95 \pm$ 6.659) không có sự khác biệt với $p=0.691$. Kết luận: Có mối liên quan giữa kháng thể anti-Sm dương tính với giảm nồng độ bổ thể và hiện tượng Raynaud. Chưa thấy mối liên quan giữa kháng thể anti-Sm với mức độ hoạt động bệnh và tổn thương các cơ quan ở bệnh nhân lupus ban đỏ hệ thống.

Tư khóa: Lupus ban đỏ hể thống, kháng thể antiSmith, biểu hiện lâm sàng, tổn thương cơ quan, SLEDAI.

\section{SUMMARY \\ CLINICAL AND LABORATORY CHARACTERISTICS OF SYSTEMIC LUPUS ERYTHEMATOSUSPATIENTS WITH POSITIVE ANTI-SMITH ANTIBODY}

Systemic lupus erythematosus (SLE) is the most common systemic autoimmune disease that predominantly affects women of reproductiveage. The hallmark of SLE is the excessive production of pathogenic antibodies recognizing self-antigens and

\footnotetext{
${ }^{1}$ Trường Đại học Y Hà Nội,

${ }^{2}$ Bềnh viện $E$

Chịu trách nhiệm chính: Nguyễn Thị Liên

Email: lienydk2013@gmail.com

Ngày nhận bài: 10.9 .2021

Ngày phản biên khoa học: 29.10.2021

Ngày duyệt bài: 12.11.2021
} trigger the immune response to cause multiple organ injuries. Anti-Sm antibodies are directed against seven snRNPs proteins. The specificity of anti-Sm antibodies for classification of SLE reached $90 \%$ in a previous study. Objectives: This study describes the clinical and laboratory characteristics of patients with systemic lupus erythematosus with anti-Smithantibody positive. Methods: Cross-sectional descriptive study on 118 patients diagnosed with systemic lupus erythematosus according to SLICC 2012 criteriawho were treated at the center of Allergology and Clinical Immunology, Bach Mai hospital from July 2020 to September 2021. Results: $51.7 \%$ of patients had positive anti-Sm antibodies; concentrated mainly in the childbearing age; female/male ratio was 9.7:1; mean age was $31.53 \pm 11,786$ years old. Positive anti-Sm antibodies were associated with decreased complement C4 $(p<0.001)$; not associated with acute skin rash $(p=0.057)$, mucosal ulceration $(p=0.103)$, arthritis $(p=0.374)$, pericardial effusion $(p=0.243)$, pleural effusion $(p=0.426)$, arthritis $(p=0,374)$, kidney damage at the level of glomerulonephritis or nephrotic syndrome $\quad(p=0.579)$, leukopenia $(p=0.582)$, thrombocytopenia $(p=0.347), C 3$ deficiency $(r=0.347$; $p=0.078)$ and positive anti-dsDNA double-stranded antibody $(p=0.187) .(r=0.076 ; p=0.207)$. The mean of SLEDAI score in the two groups with or without anti$\mathrm{Sm}(13.39 \pm 5.499$ and $12.95 \pm 6.659$, respectively) had no difference with $p=0.691$. Conclusion: There was an association between anti-Sm antibody positive with decreased complement concentration and Raynaud phenomenon and no correlation between anti-Sm antibody and SLEDAI score and some organ damage in patients with SLE.

Keywords: Systemic lupus erythematosus, AntiSmith antibodies, Clinical manifestations, Disease damage, SLEDAI.

\section{I. Đă̆T VẤN ĐỀ}

Lupus ban đỏ hệ thống (Systemic Lupus Erythematosus - SLE) là bệnh lí tự miễn phổ biến nhất trong các bệnh hệ thống, ước tính khoảng 5,8 đến 130 người mắc trên 100.000 dân[1]. SLE gặp tân suất cao hơn ở nữ giới, thay đổi giữa các quốc gia và chủng tộc, gặp chủ yếu trong độ tuổi sinh sản từ 20-40 tuổi. Đây là một bệnh tự miễn mạn tính không rõ nguyên nhân có thể ảnh hưởng đến bất kì cơ quan nào của cơ thể. Do vậy, biểu hiện lâm ien của SLE rất đa 